\title{
Synthesis and Theoretical Study of 4-(2-methyl-4- oxoquinazoline-3(4H)-yl) Benzoic acid with Some Transition Metal Ions
}

\author{
Asmaa K. Ayal*, Shaimaa R. Bakir* ,Mahasin F.Alias* \\ Received 6, March, 2012 \\ Accepted 5, December, 2012
}

\begin{abstract}
:
New complexes of the type $\left[\mathrm{ML}_{2}\left(\mathrm{H}_{2} \mathrm{O}\right)_{2}\right]$, $\left[\mathrm{FeL}_{2}\left(\mathrm{H}_{2} \mathrm{O}\right) \mathrm{Cl}\right]$ and $\left[\mathrm{VOL}_{2}\right]$ were $\mathrm{M}=\mathrm{Co}(\mathrm{II}), \mathrm{Ni}(\mathrm{II})$ and $\mathrm{Cu}$ (II) ,L=4-(2-methyl-4-oxoquinazoline-3(4H)-yl) benzoic acid were synthesized and characterized by element analysis, magnetic susceptibility ,molar conductance ,FT-IR and UV-visible. The studies indicate that the L acts as doubly monodentate bridge for metal ions and form mononuclear complexes. The complexes are found to be octahedral except V(IV) complex is square pyrimde shape . The structural geometries of compounds were also suggested in gas phase by theoretical treatments, using Hyper chem-6 program for the molecular mechanics and semi-empirical calculations, addition heat of formation $\left(\Delta \mathrm{H}_{f}{ }^{\circ}\right)$ and binding energy $\left(\Delta \mathrm{E}_{b}\right)$ for the free ligands and it's metal complexes were calculated by using PM3 method .PM3 was used to evaluate the vibration spectra of ligand and compare the theoretically calculated wave numbers with experimental values ,the theoretically obtained frequencies agreed calculation helped to assign unambiguously the most diagnostic bands.
\end{abstract}

\section{Key word:Quinazoline, complexes of oxoquinazoline,Spectral studies}

\section{Introduction:}

Heterocyclic compounds are organic compounds containing at least one atom of carbon, and at least one element other than carbon ,such as sulfur, oxygen or nitrogen within a ring structure[1,2].Heterocyclic that contains nitrogen atom is an important class of compounds, that displays a wide variety of biological activities ;therefore, these structures have received special attention in a considerable synthesis[3,4]. Much attention has been paid to the benzodiazepines, oxazepane, oxazepine, thiazepine and oxazine,for which abstracts have been reported in the libraries [5,6].Among a wide variety of nitrogen heterocyclic that have been explored for developing pharmaceutically important molecules, the quinazoline have played an important role in medicinal chemistry and subsequently have emerged as a pharmacophore[7].Recently

,nitraquazone, a quinazoline derivative has been found to possess potent phosphodiesterase inhibitory activity[7].

Material and Methods :

\section{A-Materials, physical} measurements and analysis :

The chemicals used in this work were obtained from BDH. and Fluka.They were pure grade reagents . Metal contents of the complexes were determined using a Shimadzu A.A680G atomic absorption Spectrophotometer. FTIR spectra were recorded using Shimadzo-8000 spectrophotometer using CsI discs in

*Department of Chemistry, College of Science for Women, University of Baghdad. Baghdad-Iraq 
the range $(4000-200) \mathrm{cm}^{-1}$. Electronic spectra were recorded using Shimadza UV-Visible (160A) ultra violate spectrophotometer at wave length in the range (1100-200)nm . Electrical conductivity was measured using Coring conductometer and magnetic susceptibility was measured by Johnson Matting Catalytic System Division and melting point was measured using Gallencamp M.F.B 600.01 . Elemental (C,H and $\mathrm{N}$ ) analyses were carried out on a EUROEA-Elemental analyzer Italya.<smiles>Cc1nc2ccccc2c(=O)n1-c1ccc(C(=O)O)cc1-c1cc(N)ccc1-c1ccc(C(=O)O)cc1</smiles>

\section{C- Preparation of metal complexes}

An ethanolic solution of ligand(L) $(0.45,0.02$ mole $)$ was added to a hot ethanolic and potassium hydroxide solution of metal chloride (0.01mole). The reaction mixture was refluxed on water bath for $4 \mathrm{~h}$ until a

\section{B-Praperation of ligand:-}

A mixture of 2-methyl -4-(H)-3,1benzoxazizin -4-one $(1.79 \mathrm{~g}, 10 \mathrm{mmol})$ ,para amino benzoic acid (10mmol) and pyridine $(15 \mathrm{ml})$ was heated for 3 hours. Pyridine was evaporated at reduced pressure and the residue was first treated with dilute hydrochloric acid and then with aqueous ( $1 \mathrm{~g})$ of sodium hydroxide .The product crystallized from heptanes to give 1.98 $\mathrm{g}(84 \%)$ of (L) [8] .
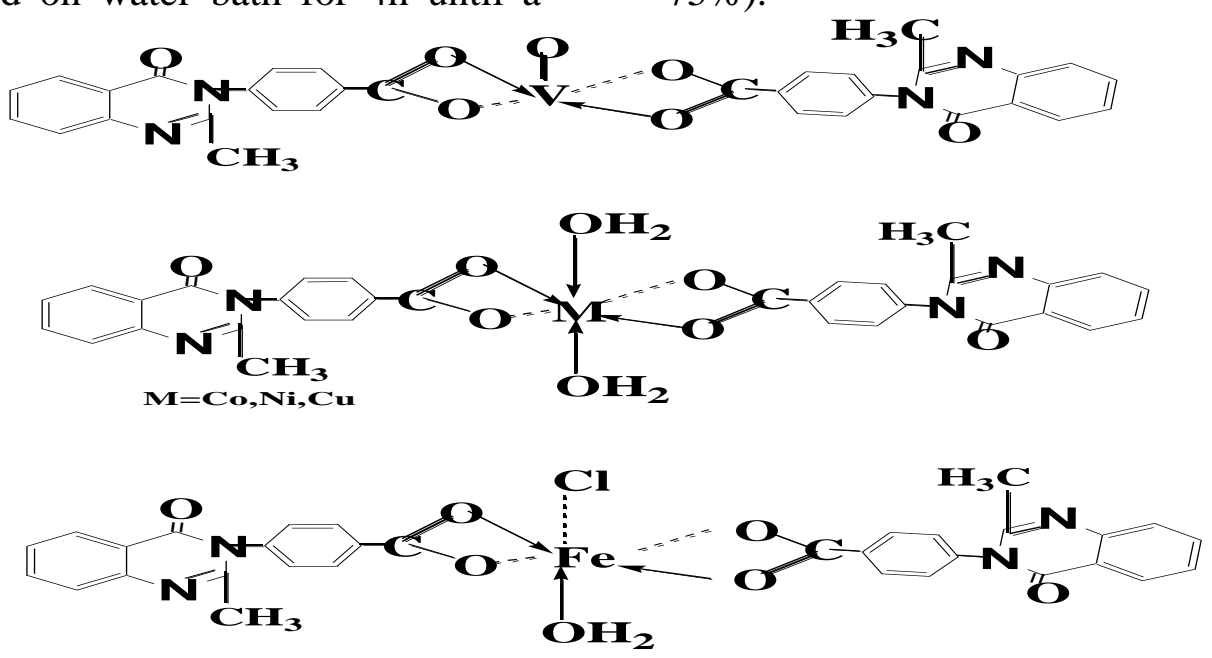
Table (1) shows the physical properties of prepared complexes

\begin{tabular}{|c|c|c|c|c|c|c|c|c|}
\hline Compound & Color & $\begin{array}{l}\text { Melting } \\
\text { point }\end{array}$ & Yield\% & $\begin{array}{l}\mathrm{C} \% \\
\text { Calcd } \\
\text { (exp) }\end{array}$ & $\begin{array}{c}\mathrm{H} \% \\
\text { Calcd } \\
\text { (Exp) }\end{array}$ & $\begin{array}{l}\mathrm{N} \% \\
\text { Calcd } \\
\text { (Exp) }\end{array}$ & $\begin{array}{l}\text { Metal\% } \\
\text { calculate } \\
\text { (found) }\end{array}$ & $\begin{array}{c}\text { Molar } \\
\text { conductance } \\
\mathrm{Ohm}^{-1} \mathrm{~cm}^{2} \\
\mathrm{~mol}^{-1}\end{array}$ \\
\hline $\mathrm{L}$ & White & 190-192 & 86 & $\begin{array}{c}68.5 \\
(67.9) \\
\end{array}$ & $\begin{array}{c}4.28 \\
(3.98) \\
\end{array}$ & $\begin{array}{c}10.00 \\
(11.02) \\
\end{array}$ & - & - \\
\hline$\left[\mathrm{Co}(\mathrm{L})_{2}\left(\mathrm{H}_{2} \mathrm{O}\right)_{2}\right]$ & $\begin{array}{l}\text { Light- } \\
\text { Green }\end{array}$ & $182-184$ & 74 & $\begin{array}{l}4.90 \\
(5.88)\end{array}$ & $\begin{array}{c}4.97 \\
(3.99)\end{array}$ & $\begin{array}{c}0.61 \\
(0.71)\end{array}$ & $\begin{array}{c}9.02 \\
(10.00)\end{array}$ & 15.15 \\
\hline$\left[\mathrm{Ni}(\mathrm{L})_{2}\left(\mathrm{H}_{2} \mathrm{O}\right)_{2}\right]$ & Brown & $178-180$ & 75 & $\begin{array}{c}4.91 \\
(4.02) \\
\end{array}$ & $\begin{array}{c}4.30 \\
(5.22) \\
\end{array}$ & $\begin{array}{c}0.61 \\
(0.65) \\
\end{array}$ & $\begin{array}{c}9.00 \\
(8.87)\end{array}$ & 17.38 \\
\hline$\left[\mathrm{Cu}(\mathrm{L})_{2}(\mathrm{H} 2 \mathrm{O})_{2}\right]$ & $\begin{array}{l}\text { Light- } \\
\text { Green }\end{array}$ & 156-158 & 61 & $\begin{array}{c}4.88 \\
(5.74)\end{array}$ & $\begin{array}{c}4.27 \\
(5.02)\end{array}$ & $\begin{array}{c}0.61 \\
(0.55)\end{array}$ & $\begin{array}{c}9.99 \\
(10.69)\end{array}$ & 19.47 \\
\hline$\left[\mathrm{Fe}(\mathrm{L})_{2}\left(\mathrm{H}_{2} \mathrm{O}\right) \mathrm{Cl}\right]$ & $\begin{array}{l}\text { Dark- } \\
\text { Brown }\end{array}$ & $122-124$ & 76 & $\begin{array}{l}4.20 \\
(3.18)\end{array}$ & $\begin{array}{c}4.20 \\
(3.20)\end{array}$ & $\begin{array}{c}0.60 \\
(0.51)\end{array}$ & $\begin{array}{c}8.38 \\
(9.34)\end{array}$ & 13.89 \\
\hline$\left[\mathrm{VO}(\mathrm{L})_{2}\right]$ & $\begin{array}{l}\text { Olive } \\
\text { green }\end{array}$ & $132-134$ & 67 & $\begin{array}{c}5.13 \\
(6.09)\end{array}$ & $\begin{array}{c}3.21 \\
(4.09)\end{array}$ & $\begin{array}{c}0.64 \\
(0,59)\end{array}$ & $\begin{array}{c}8.17 \\
(9.16)\end{array}$ & 16.36 \\
\hline
\end{tabular}

\section{Hyper Chem.}

Hyper Chem is a sophisticated molecular modeling environment that is known for its quality, flexibility, and ease of use.Uniting 3D visualization and animation with quantum chemical calculation ,molecular mechanics, and dynamics,Hyper Chem puts more molecular modeling tools at your fingertips than any other windows program.[9].

\section{Result and Discussion}

All the complexes were sparingly soluble in common organic solvents but soluble in DMF,DMSO and acetonitrile.The analytical data indicates that the complexes are agree well with 1:2 metal to ligand stoichiometry shown in (Table1).The observed molar conductance values measured in DMF solution fall in the range (13.89-19.47) $\mathrm{ohm}^{-1} \mathrm{~cm}^{2} \mathrm{~mol}^{-1}$ .These observed values of the molar conductance are well within the expected range for non-electrolytes (Table1).

\section{Magnetic Susceptibility:-}

The magnetic moments obtained at room temperature for the complexes of $\mathrm{Co}(\mathrm{II}), \mathrm{Ni}(\mathrm{II})$ and $\mathrm{Cu}(\mathrm{II})$ are listed in (Table3).The cobalt complex shows magnetic moment of 4.86 B.M the spin free octahedral complex of $\mathrm{Co}$ (II) is reported to exhibit magnetic moment in the range of 4.465.53B.M.[10]Hence observed magnetic moment for the $\mathrm{Co}(\mathrm{II})$ under study indicates that it has an octahedral configuration. The nickel complex shows magnetic moment of 2.95 B.M.The magnetic moment of octahedral $\mathrm{Ni}$ (II) complex is reported to exhibit magnetic moment in the range of 2.80-3.40B.M including spin orbital coupling[11]. Hence the observed magnetic moment for the $\mathrm{Ni}(\mathrm{II})$ complex suggests that it may have octahedral geometry. Copper complex exhibits magnetic moment 1.95 B.M.which is including the normal value [12] exhibit magnetic moment in the range of (1.842.20)B.M. including spin orbital coupling, suggests that it may have octahedral geometry.

\section{Infrared spectroscopy:-}

The FTIR spectrum for the ligand (L), shows a characteristic stretching absorption bands at 3186 $\mathrm{cm}^{-1}, 1693 \mathrm{~cm}^{-1}$ and $1362 \mathrm{~cm}^{-1}$ assigned to hydroxyl group, $v$ (COO)asym., $v$ (COO)sym., respectively[13,14] . The $v$ COO stretching vibrations are important to predict the bonding mode of the ligand.The values of $\left[\Delta v=(\mathrm{COO})_{\text {asym. }}{ }^{-}\right.$ $v(\mathrm{COO})_{\text {sym. }}$ ] can be divided into 3 
groups;(a)In compounds where $\Delta v$ $(\mathrm{COO})>350 \quad \mathrm{~cm}^{-1}$, the carboxylate group binds in a monodentate fashion.However ,other very weak intra- and intermolecular interactions cannot be excluded.(b)When $\Delta v$ (COO) $<200 \mathrm{~cm}^{-1}$, the carboxylate groups of these compounds can be considered to be bidentate.(c).In compounds where $\Delta v \quad(\mathrm{COO})>200$ $\mathrm{cm}^{-1}$ and $<350 \mathrm{~cm}^{-1}$ an intermediate state between monodentate and bidentate (anisobidentate) occurs.It has also been suggested that the $\Delta v(\mathrm{COO})$ in the chelating mode is less than the $\Delta$ $v$ (COO) in a bridging mode $[15,16]$.
The disappearance of hydrogen from hydroxyl group on complexation indicates that the complexation is through the oxygen atom.Streching of metal-oxygen bands of the complexes appeared in low frequency region [17] $(467-421) \mathrm{cm}^{-1}$. The IR data of the ligand and its complexes are shown in Table(2).In the present study of all prepared complexes of the ligand in the presence of weak band around 845$850 \mathrm{~cm}^{-1}$, which may be assigned due to the presence of coordination water molecule in the complexes[18].

Table(2)The main diagnostic absorption bands of ligand and its complexes $\left(\mathrm{cm}^{-1}\right)$

\begin{tabular}{|c|c|c|c|c|c|c|}
\hline Compound & $\mathrm{vOH}$ & $v(\mathrm{COO})_{\mathrm{asy}}$ & $v(\mathrm{COO})_{\mathrm{sym}}$ & $v \mathrm{M}-\mathrm{O}$ & v $\mathrm{M}-\mathrm{Cl}$ & Others \\
\hline $\mathrm{L}$ & 3186 & 1693 & 1362 & - & - & - \\
\hline$\left[\mathrm{Co}(\mathrm{L})_{2}\left(\mathrm{H}_{2} \mathrm{O}\right)_{2}\right]$ & - & 1680 & 1345 & 467 & & $\begin{array}{l}\delta_{\mathrm{H} 2 \mathrm{O}}=845 \\
v_{\mathrm{H} 2 \mathrm{O}}=3441\end{array}$ \\
\hline$\left[\mathrm{Ni}(\mathrm{L})_{2}\left(\mathrm{H}_{2} \mathrm{O}\right)_{2}\right]$ & - & 1677 & 1340 & 432 & & $\begin{array}{c}\delta_{\mathrm{H} 2 \mathrm{O}}=840 \\
v_{(\mathrm{H} 2 \mathrm{O}}=3313\end{array}$ \\
\hline$\left[\mathrm{Cu}(\mathrm{L})_{2}\left(\mathrm{H}_{2} \mathrm{O}\right)_{2}\right]$ & - & 1675 & 1375 & 421 & & $\begin{array}{c}\delta_{\mathrm{H} 2 \mathrm{O}}=848 \\
v_{(\mathrm{H} 2 \mathrm{O})}=3387\end{array}$ \\
\hline$\left[\mathrm{Fe}(\mathrm{L})_{2}\left(\mathrm{H}_{2} \mathrm{O}\right) \mathrm{Cl}\right]$ & - & 1710 & 1390 & 443 & 367 & $\begin{array}{c}\delta_{\mathrm{H} 2 \mathrm{O}}=850 \\
v_{(\mathrm{H} 2 \mathrm{O})}=3417\end{array}$ \\
\hline$\left[\mathrm{VO}(\mathrm{L})_{2}\right]$ & - & 1671 & 1339 & 453 & & $\mathrm{~V}=\mathrm{O}=972$ \\
\hline
\end{tabular}

\section{Electronic Spectra:-}

The electronic spectral data of $\mathrm{Co}(\mathrm{II}), \mathrm{Ni}(\mathrm{II}), \mathrm{Cu}(\mathrm{II}), \mathrm{Fe}(\mathrm{III}) \quad$ andV(IV) complexes were recorded in DMF as shown in Table(3). The Co(II) complex (light green), the electronic absorption bands appears at 9985 and $20089 \mathrm{~cm}^{-1}$ , due to ${ }^{4} \mathrm{~T}_{1} \mathrm{~g}_{(\mathrm{F})} \rightarrow{ }^{4} \mathrm{~A}_{2} \mathrm{~g}$ and ${ }^{4} \mathrm{~T}_{1} \mathrm{~g}_{(\mathrm{F})} \rightarrow{ }^{4} \mathrm{~T}_{1} \mathrm{~g}_{(\mathrm{P})}$ transition respectively in an octahedral environment[19]. The electronic spectrum of $\mathrm{Ni}$ (II) complex shows two bands at 10810 and 25316 $\mathrm{cm}^{-1}$ assignable to ${ }^{3} \mathrm{~A}_{2} \mathrm{~g} \rightarrow{ }^{3} \mathrm{~T}_{2} \mathrm{~g}_{(\mathrm{F})}$ and ${ }^{3} \mathrm{~A}_{2} \mathrm{~g} \rightarrow{ }^{3} \mathrm{~T}_{1} \mathrm{~g}_{(\mathrm{P})}$ transition respectively ,in octahedral environment[20]. The light green colored of $\mathrm{Cu}$ (II) complex exhibits a broad band in the region
16395-12195 $\mathrm{cm}^{-1}$ with maxima at $12210 \mathrm{~cm}^{-1}$ in a distorted octahedral geometry [21].The broadness of the band may be due to dynamic JannTeller distortion and is assigned to ${ }^{2} \mathrm{Eg} \rightarrow{ }^{2} \mathrm{~T}_{2} \mathrm{~g}$ transitions. The electronic spectrum of $\mathrm{Fe}(\mathrm{III})$ complex shows three bands at 10857,15822 and 21740 $\mathrm{cm}^{-1}$ assignable to ${ }^{6} \mathrm{~A}_{1} \mathrm{~g} \rightarrow{ }^{4} \mathrm{~T}_{1} \mathrm{~g}(\mathrm{G}),{ }^{6} \mathrm{~A}_{1} \mathrm{~g} \rightarrow{ }^{4} \mathrm{~T}_{2} \mathrm{~g}(\mathrm{G}) \quad$ and ${ }^{6} \mathrm{~A}_{1} \mathrm{~g} \rightarrow{ }^{4} \mathrm{~A}_{1} \mathrm{~g}+{ }^{4} \mathrm{Eg}(\mathrm{G}) \quad$ [22].The Vanadium complex colored of the electronic absorption bands appears at $13888 \mathrm{~cm}^{-1}$ and $18181 \mathrm{~cm}^{-1}$, due to ${ }^{2} \mathrm{~B}_{2} \mathrm{~g} \rightarrow{ }^{2} \mathrm{Eg} \quad$ and ${ }^{2} \mathrm{~B}_{2} \mathrm{~g} \quad \rightarrow{ }^{2} \mathrm{~B}_{1} \mathrm{~g}$ transition[23]. 
Table(2) Electronic spectra, magnetic moment(B.M) and The Structure

Suggested for the present prepared metal complexes of ligands

\begin{tabular}{|c|c|c|c|c|c|c|c|c|}
\hline Compound & $\begin{array}{l}\text { Wave nu } \\
\text { mber cm- }{ }^{1}\end{array}$ & $\begin{array}{c}\text { (d-d) } \\
\text { Transitions }\end{array}$ & B & $\mathrm{Dq}$ & $10 \mathrm{Dq}$ & B & $\begin{array}{r}\text { Structure } \\
\text { Suggest }\end{array}$ & $\begin{array}{c}\mu e f f \\
(\mathbf{B M})\end{array}$ \\
\hline $\mathrm{L}$ & $\begin{array}{l}325 \\
433\end{array}$ & - & - & - & - & - & - & - \\
\hline$\left[\mathrm{Co}(\mathrm{L})_{2}\left(\mathrm{H}_{2} \mathrm{O}\right)_{2}\right]$ & $\begin{array}{r}9985 \\
15439_{\text {(Cal.) }} \\
20089\end{array}$ & $\begin{array}{r}{ }^{4} \mathrm{~T}_{1} \mathrm{~g}_{(\mathrm{F})} \rightarrow{ }^{4} \mathrm{~A}_{2} \mathrm{~g}, \\
{ }^{4} \mathrm{~T}_{1} \mathrm{~g}_{(\mathrm{F})} \rightarrow{ }^{4} \mathrm{~A}_{2} \mathrm{~g}_{(\mathrm{F})} \\
{ }^{4} \mathrm{~T}_{1} \mathrm{~g}_{(\mathrm{F})} \rightarrow{ }^{4} \mathrm{~T}_{1} \mathrm{~g}_{(\mathrm{P})}\end{array}$ & 930 & 825 & 8250 & 0.958 & octahedral & 4.86 \\
\hline$\left.\left[\mathrm{Ni}(\mathrm{L})_{2(} \mathrm{H}_{2} \mathrm{O}\right)_{2}\right]$ & $\begin{array}{r}10810 \\
15151_{\text {(Cal.) }} \\
25316 \\
\end{array}$ & $\begin{array}{l}{ }^{3} \mathrm{~A}_{2} \mathrm{~g} \rightarrow{ }^{3} \mathrm{~T}_{2} \mathrm{~g}_{(\mathrm{F})} \\
{ }^{3} \mathrm{~A}_{2} \mathrm{~g} \rightarrow{ }^{3} \mathrm{~A}_{1} \mathrm{~g}_{(\mathrm{F})} \\
{ }^{3} \mathrm{~A}_{2} \mathrm{~g} \rightarrow{ }^{3} \mathrm{~T}_{1} \mathrm{~g}_{(\mathrm{P})}\end{array}$ & 834 & 932 & 9320 & 0.820 & octahedral & 2.95 \\
\hline$\left[\mathrm{Cu}(\mathrm{L})_{2}\left(\mathrm{H}_{2} \mathrm{O}\right)_{2}\right]$ & 12210 & ${ }^{2} \mathrm{Eg} \rightarrow{ }^{2} \mathrm{~T}_{2} \mathrm{~g}$ & - & - & - & - & octahedral & 1.95 \\
\hline $\left.\mathrm{Fe}(\mathrm{L})_{2}\left(\mathrm{H}_{2} \mathrm{O}\right) \mathrm{Cl}\right]$ & $\begin{array}{l}10857 \\
15822 \\
21740\end{array}$ & $\begin{array}{r}{ }^{6} \mathrm{~A}_{1} \mathrm{~g} \rightarrow{ }^{4} \mathrm{~T}_{1} \mathrm{~g}_{(\mathrm{G})} \\
{ }^{6} \mathrm{~A}_{1} \mathrm{~g} \rightarrow{ }^{4} \mathrm{~T}_{2} \mathrm{~g}_{(\mathrm{G})} \\
{ }^{6} \mathrm{~A}_{1} \mathrm{~g} \rightarrow{ }^{4} \mathrm{~A}_{1} \mathrm{~g}+{ }^{4} \mathrm{Eg}_{(\mathrm{G})}\end{array}$ & 1300 & 120 & 1200 & 0.53 & octahedral & 5.01 \\
\hline$\left[\mathrm{VO}(\mathrm{L})_{2}\right]$ & $\begin{array}{l}13888 \\
18181\end{array}$ & $\begin{array}{r}{ }^{2} \mathrm{~B}_{2} \mathrm{~g} \rightarrow{ }^{2} \mathrm{Eg} \\
{ }^{2} \mathrm{~B}_{2} \mathrm{~g} \rightarrow{ }^{2} \mathrm{~B}_{1} \mathrm{~g}\end{array}$ & & & & & $\begin{array}{r}\text { Square } \\
\text { Pyrimde }\end{array}$ & 1.53 \\
\hline
\end{tabular}

HOMO and LUMO orbitals:-

( $\mathrm{HOMO}$ ) to highest occupied molecular orbital and (LUMO) lowest unoccupied Molecular orbital .These orbitals are called the frontier orbitals,and determine the way the molecule interacts with other species. The HOMO is the orbital that could act as an electron donor, since it is the outermost(highest energy) orbital containing electrons. The LUMO is the orbital that could act as the electron acceptor since it is the innermost(lowest energy)orbital that has room to accept electrons. In accordance with the above definitions, a single orbital may be both the LUMO and HOMO[24]. 


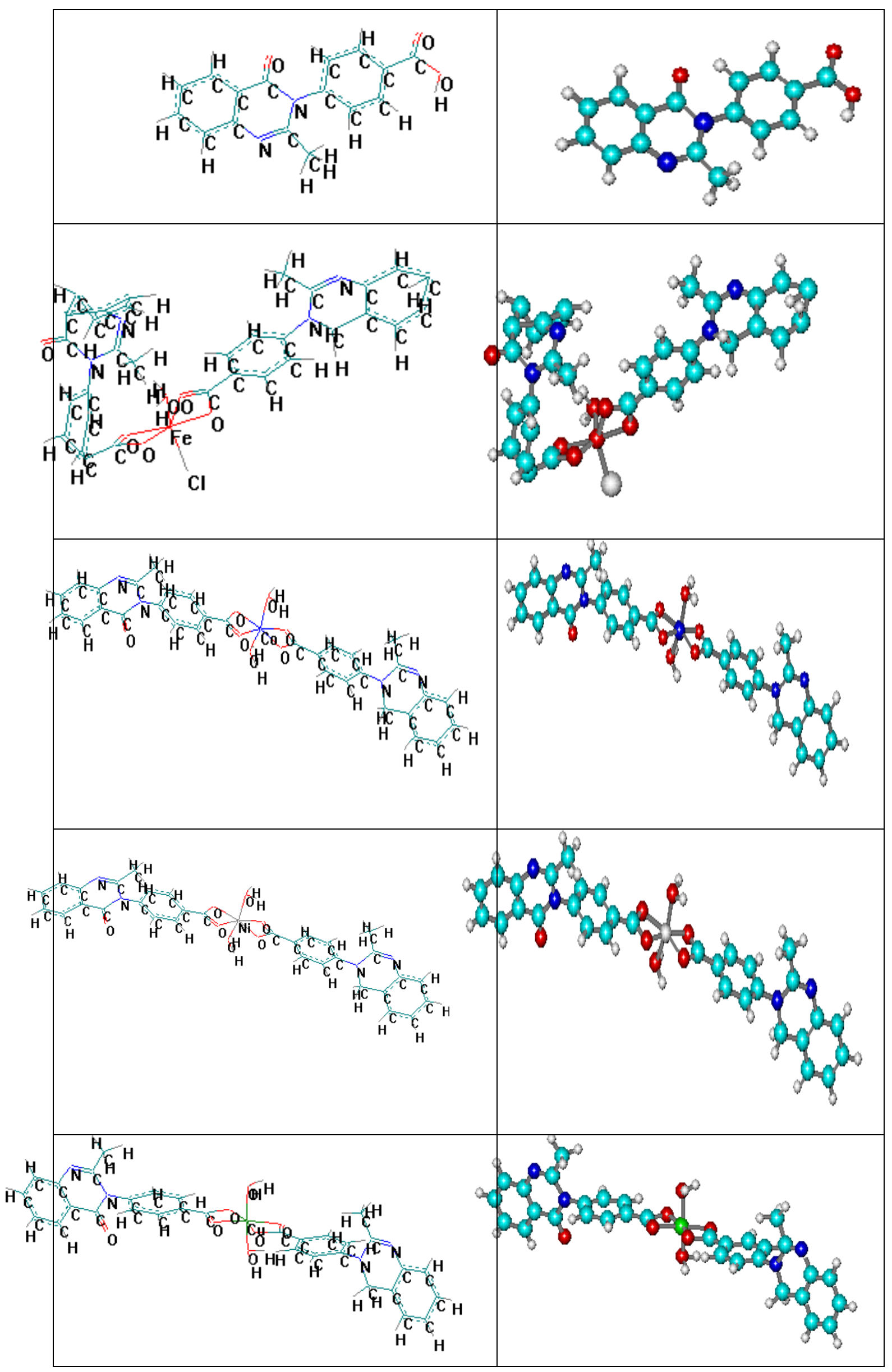




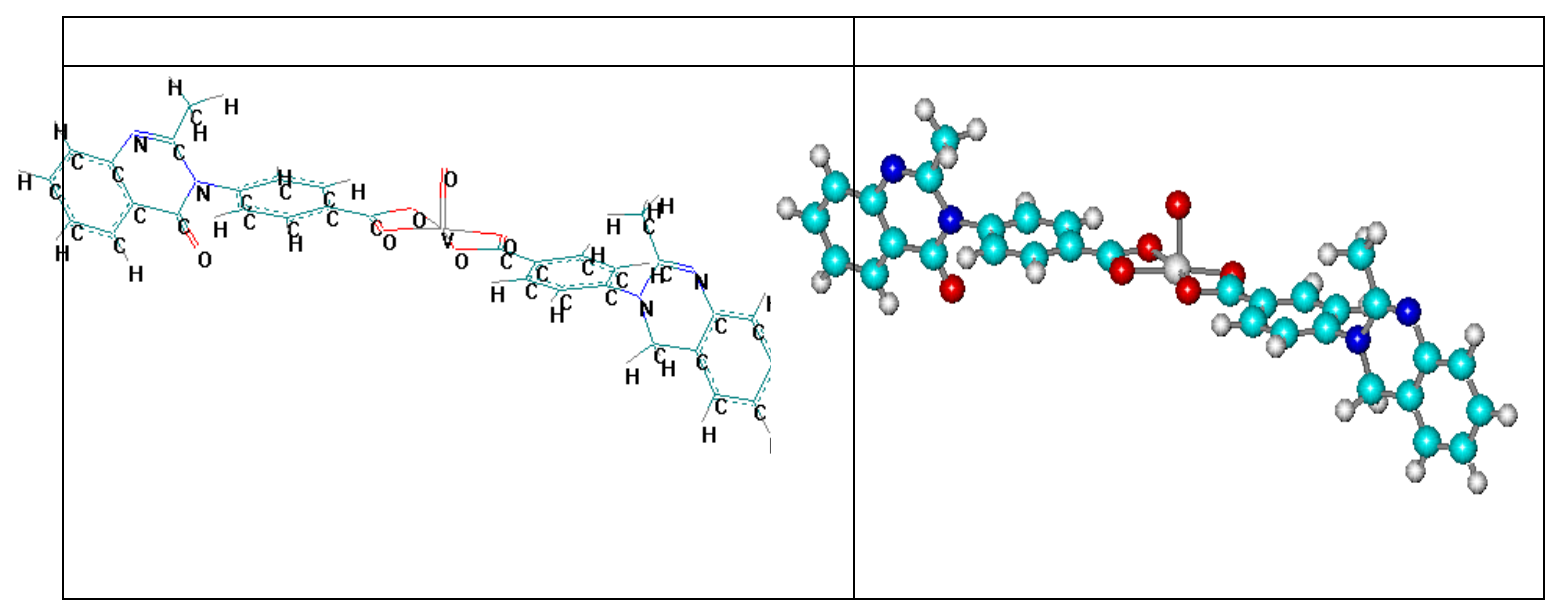

Fig(1) Conformational Structure of the ligand and their Complexes

Table (4): Conformation energetic in $\left(\mathrm{KJ}_{\mathrm{Mol}}{ }^{-1}\right)$ for imines $\left(\mathrm{L}^{1}\right)$ and its metal complexes

\begin{tabular}{|c|c|c|}
\hline \multirow{2}{*}{ Conformation } & \multicolumn{2}{|c|}{ PM3 } \\
\hline & $\Delta \mathbf{H}_{f}^{\circ}$ & $\Delta \mathbf{E}_{\boldsymbol{b}}$ \\
\hline $\mathrm{L}$ & 12.378933 & -2198.8560667 \\
\hline$\left[\mathrm{Co}(\mathrm{L})_{2}\left(\mathrm{H}_{2} \mathrm{O}\right)_{2}\right]$ & -65.0953082 & -4280.6713082 \\
\hline$\left[\mathrm{Ni}(\mathrm{L})_{2}\left(\mathrm{H}_{2} \mathrm{O}\right)_{2}\right]$ & $\begin{array}{c}- \\
8312.777312\end{array}$ & -12695.2143127 \\
\hline$\left[\mathrm{Cu}(\mathrm{L})_{2}\left(\mathrm{H}_{2} \mathrm{O}\right)_{2}\right]$ & -94.3439130 & -4359.7960870 \\
\hline $\left.\mathrm{Fe}(\mathrm{L})_{2}\left(\mathrm{H}_{2} \mathrm{O}\right) \mathrm{Cl}\right]$ & $\begin{array}{c}- \\
9238.608342 \\
\end{array}$ & -13688.2983428 \\
\hline$\left[\mathrm{VO}(\mathrm{L})_{2}\right]$ & $\begin{array}{c}- \\
163.4977939 \\
\end{array}$ & -244.507529544 \\
\hline
\end{tabular}

Table (5): Comparison of experimental and theoretical vibration Frequencies for the

\begin{tabular}{|c|c|c|c|}
\hline Comp. & $v(\mathrm{COO})$ asym. & $v(\mathrm{COO})$ sym. & $v \mathrm{OH}$ \\
\hline \multirow{2}{*}{$\mathrm{L}^{1}$} & $(1693)^{*}$ & $(1369)^{*}$ & $(3186)^{*}$ \\
& $(1705)^{* *}$ & $(1333)^{* *}$ & $(3100)^{* *}$ \\
& $(-0.70)^{* * *}$ & $(2.62)^{* * *}$ & $(2.00)^{* * *}$ \\
\hline
\end{tabular}




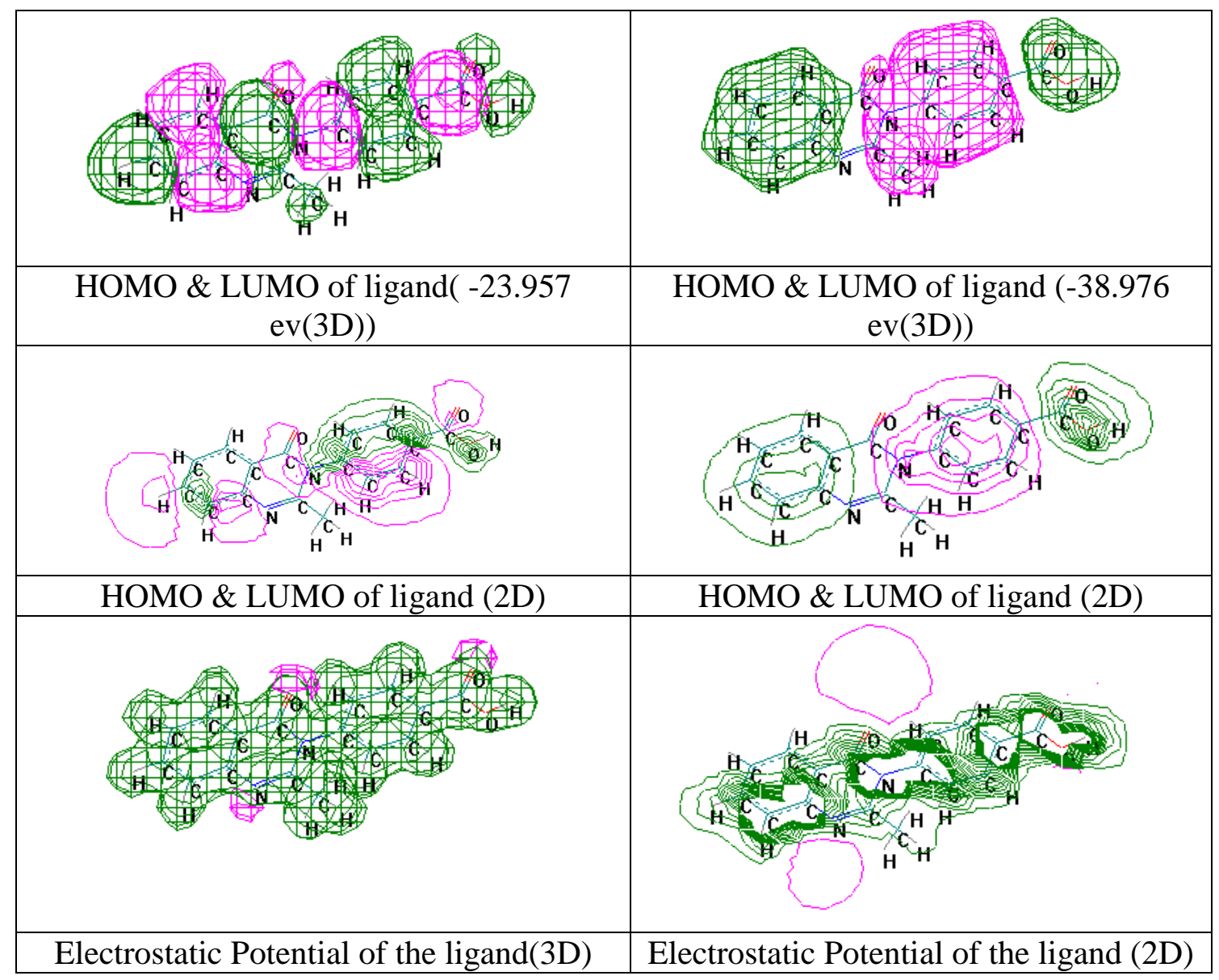

Fig(2) HOMO \& LUMO and Electrostatic Potential as 2D\&3D Contours for the ligand

\section{References:}

1-Jrjun K.R. ,Nayan R.P.,Harish R.D. and Sunil S.N .2009. Novel synthesis and characterization of thiosemicarbazone compounds containing 4-acyl -2pyrazolin -5-ones.E-J. of chem...6 (3) 747-752,.

2- Vashi, R.T.V.Shelat.,C.D and Himanshu P.2010. Synthesis and Antifungal Activity of 6-Bromo-2[(4(2,3Dichloro Phenyl ))Piperazine -1yl)Methyl ]-3-[8-Hydroxy Quinoline 5-yl]-3-Quinazoline-4-one Ligand and its Transition Metal Chelates.International J. Appl Bio. Pharma. Techn. 1 ( 3 ) 885-889.

3- Siddappa, K.Tukaram R., Mallikarjun ,M. and Reddy ,CV. 2008. Synthesis,Characterization and Antimicrobialu Studies of 3-[2Hydroxy-quinolin-3-ylmethylene)amino-2-phenyl-3H-quinazolin-4-one and its metal(II) Complexes"E-J. chem. 5 (1) 155-162,.

4-Varsha J.,Pradeep M.,and Sush K.2008. Synthesis and CNS depressant activity of some novel 3-[5-substituted 1,3,4thiadiazole-2-yl]-2-styryl quinazoline 4(3H)-ones"Eur. J. med. chem..43(1) 135-141.

5-Valerian D.and lleana D.2009. "Ruthenium Complexes Bearing NHeterocyclic Carbene (NHC) Ligands"Pt. Metal Rev..49(4) 183-188.

6- Pandey R.N. and Nag A.K. 2009. spectral characterization of some oxometal complexes of 2-mercapto-3butyl -quinazoline-4-one.rasayan j.chem.,.2 ( 4) 990-993.

7-Cathleen M.Crudden and Daryl P. Allen.2004. Stability and reactivity of N-heterocyclic d

8- Rabilloud G. and Sillion. B.1980.Synthesis of 4H-3,1- 
Benzoxazin -4-one and 4- $(3 \mathrm{H})$ Quinazolines from Anthranilic Acids and their Derivative by the Use of Triphenyl Phosphite and Pyridine. j.Hetr.Cycl.chem 17(29)1065-1068.

9- Mueller ,M. 2002. Fundamentals of Quantum Chemistry.,Kluwer Academic publishers, New York.

10- Nicholls,N. 1973. The chemistry of iron,cobalt and nickel .pengamou press,ltd Heading Ton Hill Hall,oxford,Eng.p.1053,1113.

11- Geary ,WJ. 1971. The use of conductivity measurements inorganic solvents for the characterization of coordination compounds.Coord. Chem. Rev. 7(1):81-122.

12-Sunmaz,M. and Sekerci,M. 2002. Synthesis and characterization of $\mathrm{Cu}(\mathrm{II}), \mathrm{Co}(\mathrm{II}), \mathrm{Ni}(\mathrm{II})$ and $\mathrm{Zn}$ (II)Schiff base complexes from 1-amino-5benzoyl -4-phenyl -H-pyrimidine -2one with salicylaldehyde.Polish J.Chem.76 (2) 907- 914.

13- Bakir, Sh.R.2007. Thesis,MSc ,College of Science for women ,University of Baghdad .Synthesis and Characterization of some new Schiff Bases and Their Complexes with Selection of Elements and Their Theoretical Study.

14 -.Bakir Sh. R., Kadhim N. J.and Alias M. F..2010. Synthesis, Structure Study and Theoretical Treatment of New Some Metal Complexes With 2hydroxy-4-nitro Phenyl 2-N(4-N,N dimethyl )Benzyliden. Al-Mustans. J.Sci.21 (2) 41-56.

15- Yousif E.and Rentschler E.2010. Synthesis and characterization of some metal ions with [5-(4-cholrophenyl)1,3,4-oxadiazol -2-yl]thio acetic acid. J. of Al-Nahr. univers. 13(2) 86-92.

16- El-Said A. I., A. Aly A. M., ElMeligy M. S. and Ibrahim M. A..2009. Mixed Ligand Zinc(II) and Cadmium(II) Complexes Containing Ceftriaxone or Cephradine Antibiotics and Different Donors, The Journal of the Argentine Chemical Society Vol. 97 No 2,149-165.

17- Nakamoto, N. 2009. Infrared and Raman Spectra of Inorganic and Coordination Compounds. 6th Ed,Part 2 John wiley and Sons,Inc.,New Jersy

18- Sliverstein,R.M. and Webser ,X.F. 2005. Spectrometric Identification of Organic Compounds . 7th

Ed., Jon Wiley and Son's Inc, USA .

19- Soloman, E.I. and Lever, A.B.P.2006. Inorganic Electronic Structure and Spectroscopy.Applications and Case Studies.Vol.II,John Wiley and Sons.Inc, New York Chester ,Singapore ,Toranto .

20-.Huheey J.H. 1994. Inorganic Chemistry Principle of Structure and Reactivity . Harper

internation, Edition, Harper and Row papar And Row publishers, New York,.

21- Shriver D.F. and Atkins P.W. 2001. Inorganic Chemistry $.3^{\text {rd }}$ ed ., oxford university press.

22-Vashi,R.T., and Shelat,C.D. 2010. Transition Metal Complexation Studies on Hetereo cyclic Ligands. Asian J.Chem.22(3) 1745-1750.

23- Vashi R.T. and Patel S.B.2009. Synthesis, Characterization and Antifungal Activity of Novel Quinazoline 4-One Derivatives Containing 8-Hydroxo Quinazoline Ligands and its Various Metal Complexes. E-J.Chem.6(S1)S445S451.

24-, Bakir Sh.R., Kareem T.A.A., and, Alias M.F. 2010. Synthesis, structural study and antibacterial activity of some new complexes with 2-N(4$\mathrm{N}, \mathrm{N}$-dimethyl benzyliden )-5-(P-iodo phenyl)-1,3,4-thiodiazole with $\mathrm{Cr}(\mathrm{III}), \mathrm{Mn}(\mathrm{II})$, and $\mathrm{Cd}(\mathrm{II})$ ions., J. of AlNahr. Univers. .13(2):8-19, 


\section{تحضير ودراسة H)-يل)حامض البنزوك مع بعض أيونات العناصر الانتقالية

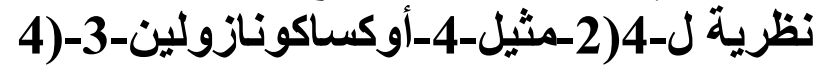

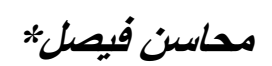

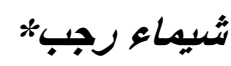

اسعاء كاظم

* جامعة بغداد/كلية العلوم للبنات



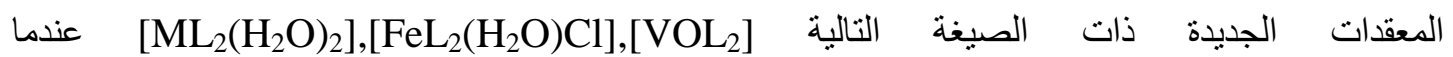

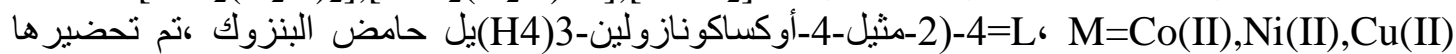

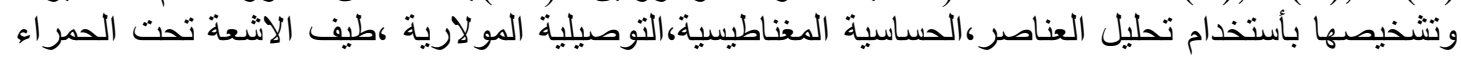

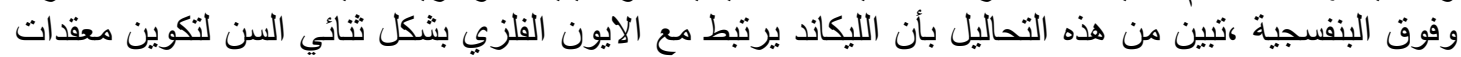

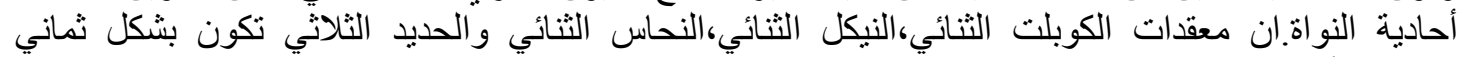

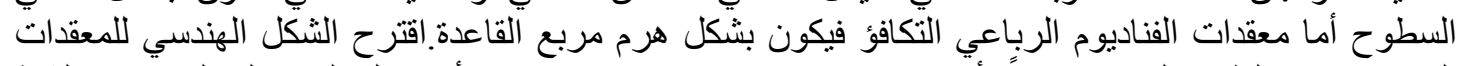

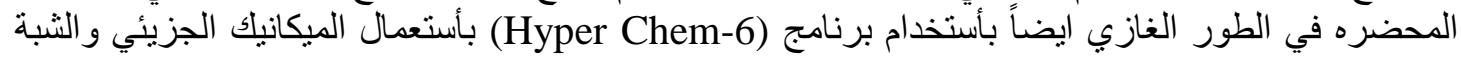

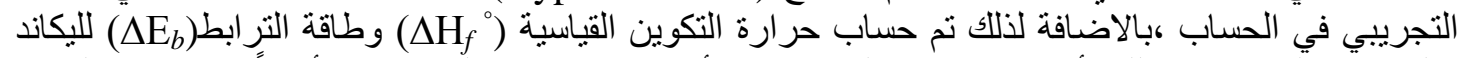

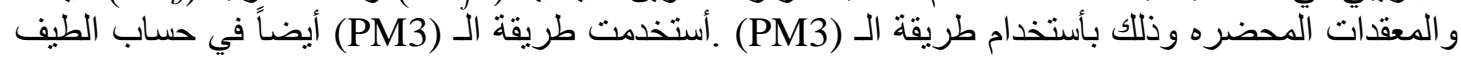

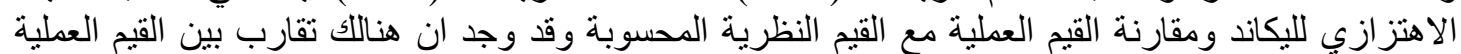
و النظرية للتردد الاهتزازي المحسوب بالمساعده في تشخيص الحزم الغير الواضحه. 